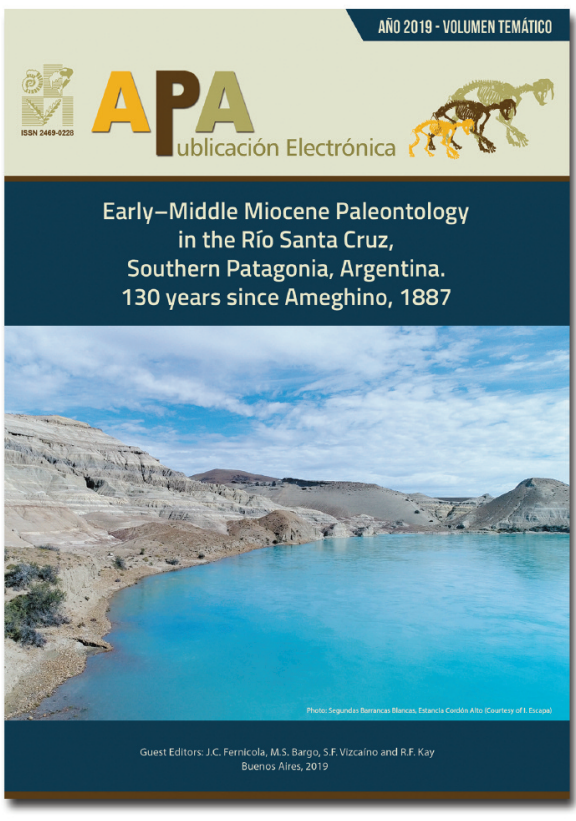

\title{
NEW RECORDS OF BIRDS FROM THE SANTA CRUZ FORMATION (EARLY- MIDDLE MIOCENE) AT THE RÍO SANTA CRUZ VALLEY, PATAGONIA, ARGENTINA
}

JUAN M. DIEDERLE'

JORGE I. NORIEGA ${ }^{1}$

${ }^{1}$ Laboratorio de Paleontología de Vertebrados, Centro de Investigación Científica y de Transferencia Tecnológica a la Producción (CICYTTP-Consejo Nacional de Investigaciones Científicas y Técnicas, Gobierno de la Provincia de Entre Ríos, Universidad Autónoma de Entre Ríos). España y Materi s/n, E3105BWA Diamante, Argentina.

Recibido: 18 de marzo 2019 - Aceptado: 16 de septiembre 2019

Para citar este artículo: Juan M. Diederle, and Jorge I. Noriega (2019). New records of birds from the Santa Cruz Formation (Early-Middle Miocene) at the Río Santa Cruz valley, Patagonia, Argentina. Publicación Electrónica de la Asociación Paleontológica Argentina 19 (2): 55-61.

Link a este artículo: http://dx.doi.org/10.5710/PEAPA.16.09.2019.284

DESPLAZARSE HACIA ABAJO PARA ACCEDER AL ARTÍCULO

Otros artículos en Publicación Electrónica de la APA 19(2):
Asociación Paleontológica Argentina Maipú $6451^{\circ}$ piso, C1006ACG, Buenos Aires

República Argentina

Tel/Fax (54-11) 4326-7563 Web: www.apaleontologica.org.ar

\section{J.C. Fernícola et al.}

HISTORICAL BACKGROUND FOR A REVISION OF THE PALEONTOLOGY OF THE SANTA CRUZ FORMATION (EARLYMIDDLE MIOCENE) ALONG THE RÍO SANTA CRUZ, PATAGONIA, ARGENTINA

\section{G. Schmidt}

LITOPTERNA (MAMMALIA) FROM THE SANTA CRUZ FORMATION (EARLY-MIDDLE MIOCENE) AT RÍO SANTA CRUZ, SOUTHERN ARGENTINA

\section{Arnal et al.}

MIOCENE CAVIOMORPHS FROM THE RÍO SANTA CRUZ (ARGENTINEAN PATAGONIA): AN UPDATE OF THIS CHARACTERISTIC RODENT FAUNA 


\title{
NEW RECORDS OF BIRDS FROM THE SANTA CRUZ FORMATION (EARLY-MIDDLE MIOCENE) AT THE RÍO SANTA CRUZ VALLEY, PATAGONIA, ARGENTINA
}

\author{
JUAN M. DIEDERLE', AND JORGE I. NORIEGA'1
}

'Laboratorio de Paleontología de Vertebrados, Centro de Investigación Científica y de Transferencia Tecnológica a la Producción (CICYTTP-Consejo Nacional de Investigaciones Científicas y Técnicas, Gobierno de la Provincia de Entre Ríos, Universidad Autónoma de Entre Ríos). España y Materi s/n, E3105BWA Diamante, Argentina.juandiederle@yahoo.com.ar; cidnoriega@infoaire.com.ar

Key words. Avifauna. Phorusrhacidae. Tinamidae. Rheidae. Neogene.

Palabras clave. Avifauna. Phorusrhacidae. Tinamidae. Rheidae. Neógeno.

The Santa Cruz Formation (SCF) constitutes one of the most representative units of the Early-Middle Miocene (Burdigalian-early Langhian) of South America for its abundant fossil record and the richness of its bird species. This record was collected during paleontological expeditions from the mid-nineteenth century along extensive outcrops exposed throughout a large area of the homonymous province. Seventeen species grouped in 15 genera and at least 10 families (Rheidae, Tinamidae, Phorusrhacidae, Cariamidae, Aramidae, Threskiornithidae, Falconidae, Brontornithidae, Anhimidae?, Anatidae and Anhingidae) constitute the diversity of extinct birds known so far (Degrange et al., 2012).

The SCF crops out in much of the territory of the Province of Santa Cruz (Argentina), in the northwest, in the surroundings of Lago Posadas, the central region along Río Santa Cruz (Fernicola et al., 2014; Cuitiño et al., 2016) and Río Chalía (= Sehuén; Vizcaíno et al., 2018) and, in the southeast, along the Atlantic coast (Vizcaíno et al., 2012). It is a continental unit composed of mudstones, tuffaceous sandstones and tuffs deposited in fluvial environments under the influence of intense explosive pyroclastic input. For extensive geological descriptions, see Cuitiño et al. (2016, 2019a). The radiometric ages for the entire SCF span the interval $\sim 18$ to $15.60 \mathrm{Ma}$, being 18-16 Ma for the Atlantic coastal localities (Fleagle et al., 2012; Perkins et al., 2012); 18.2015.60 Ma for the Río Bote and the Río Santa Cruz localities (Cuitiño et al., 2016), and 18-14 Ma for the Lago Posadas region (Perkins et al., 2012; Cuitiño et al., 2019b).

The SCF along Río Santa Cruz was recently studied and described in three locations by Fernicola et al. (2014) and Cuitiño et al. (2016, 2019a); that is, from east to west: Barrancas Blancas (BB; Estancias Santa Lucía and Aguada Grande), Segundas Barrancas Blancas (SBB; Estancias Cordón Alto, El Tordillo and Rincón Grande) and Yaten Huageno (YH; Estancia El Refugio) (Fig. 1). In the present contribution, we present and describe the first records of birds from these localities, with accurate geographic and stratigraphic provenances, along Río Santa Cruz.

\section{MATERIAL AND METHODS}

Recent fieldwork carried out throughout 2013 and 2014 by joint expeditions of Museo de La Plata (MLP), La Plata, Argentina, Museo Argentino de Ciencias Naturales "Bernardino Rivadavia" (MACN), Buenos Aires, Argentina, and Duke University, North Carolina, USA, recovered nine remains of fossil birds. This collection belongs to Museo Regional Provincial "Padre Manuel Jesús Molina" (MPM-PV), Río Gallegos, Argentina. The specimens collected exclusively include postcranial elements (e.g., fragmentary long bones, 
several pes and manus elements). These were recovered from three fossiliferous localities: Barrancas Blancas (BB; seven specimens), Segundas Barrancas Blancas (SBB; one specimen) and Yaten Huageno (YH; one specimen). The osteological nomenclature follows Howard (1929) and Baumel and Witmer (1993).

\section{SYSTEMATIC PALEONTOLOGY}

Order CARIAMIFORMES Verheyen, 1957

Family PHORUSRHACIDAE (Ameghino, 1889)

Genus Psilopterus Moreno and Mercerat, 1891

Type species. Psilopterus comunis Moreno and Mercerat, 1891. Santa Cruz Formation, Province of Santa Cruz, Argentina.

Psilopterus lemoinei (Moreno and Mercerat, 1891)

Figure 2.1-14

Referred material. MPM-PV 18897, associated fragments of a single specimen consisting of right scapula, two proximal ends of humeri (one right and one left), distal end of left radius, left proximal phalanx of digitus majoris, synsacrum plus pelvis, two distal ends of femora (one right and one left), distal end of left tibiotarsus, right proximal and right distal ends of tarsometatarsi, and proximal end of an indetermi- nate phalanx of the foot; MPM-PV 18898, synsacrum plus articulated pelvis and partial vertebral column.

Geographic occurrence. Both specimens come from the BB locality in the Estancia Santa Lucía, Province of Santa Cruz. Stratigraphic occurrence. Santa Cruz Formation (Early-Middle Miocene).

Description. The specimen MPM-PV 18897 is referred to Psilopterus lemoinei based on the following diagnostic characters described by Degrange and Tambussi (2011): humerus with crista deltopectoralis weakly developed and lacking pneumatic foramen; femur with crista lateralis of sulcus patellaris interrupted proximally before the contact with shaft; tibiotarsus with sulcus extensorius deep and medially positioned; tarsometatarsus with hypotarsus possessing two reduced cristae hypotarsi on the plantar surface: crista medialis hypotarsi lightly furrowed, with short posterior development, and crista lateralis hypotarsi slightly convex; margin of hypotarsus not protruded proximally; foramina vascularia proximalia visible in plantar view and placed at the same level; ridge of cotyla medialis high and oval; eminentia intercotylaris well developed.

The synsacrum MPM-PV 18898 is also referred to Psilopterus based on the presence of a well-developed process of the ilium, which constitutes a cranially directed spine, caudally located with respect to the foramen ilioischiadicum (Degrange et al., 2015b). Additionally, the size of this specimen is similar to that of MPM-PV 18897, precluding its

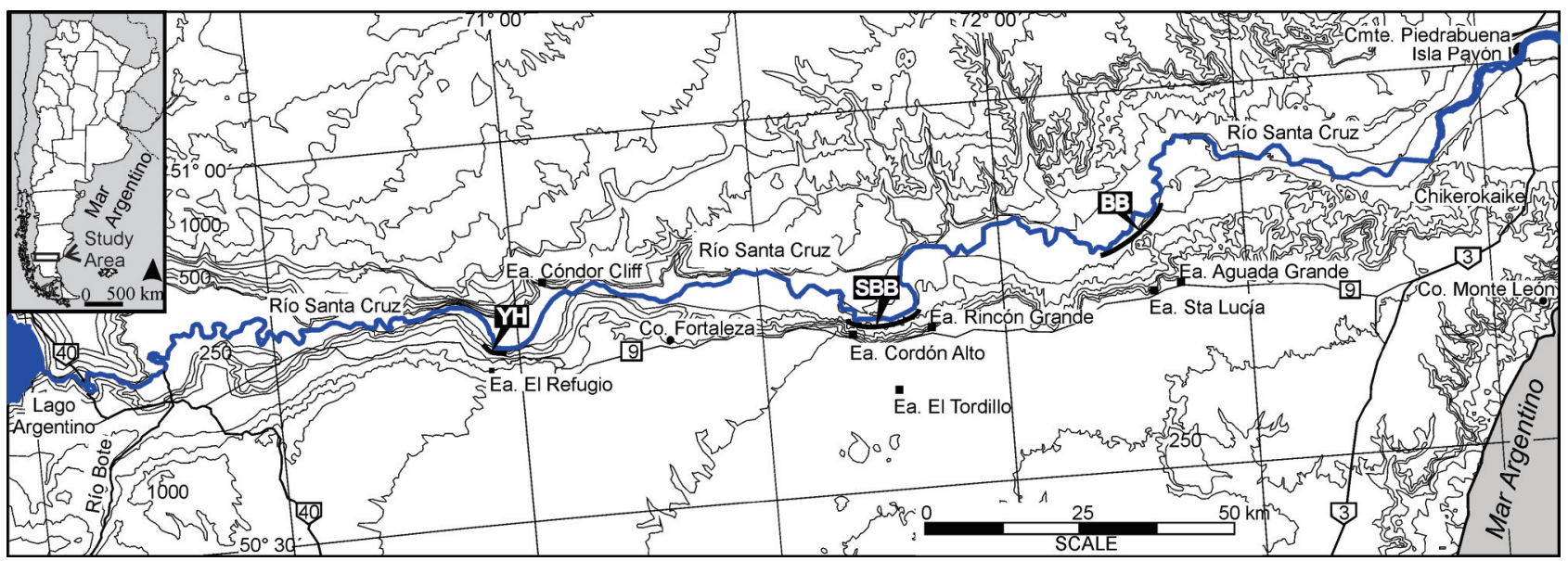

Figure 1. Geographical location of the fossiliferous localities studied at Río Santa Cruz. SBB, Segundas Barrancas Blancas; BB, Barrancas Blancas; YH, Yaten Huageno; Ea., Estancia. Modified from Fernicola et al. (2014). 


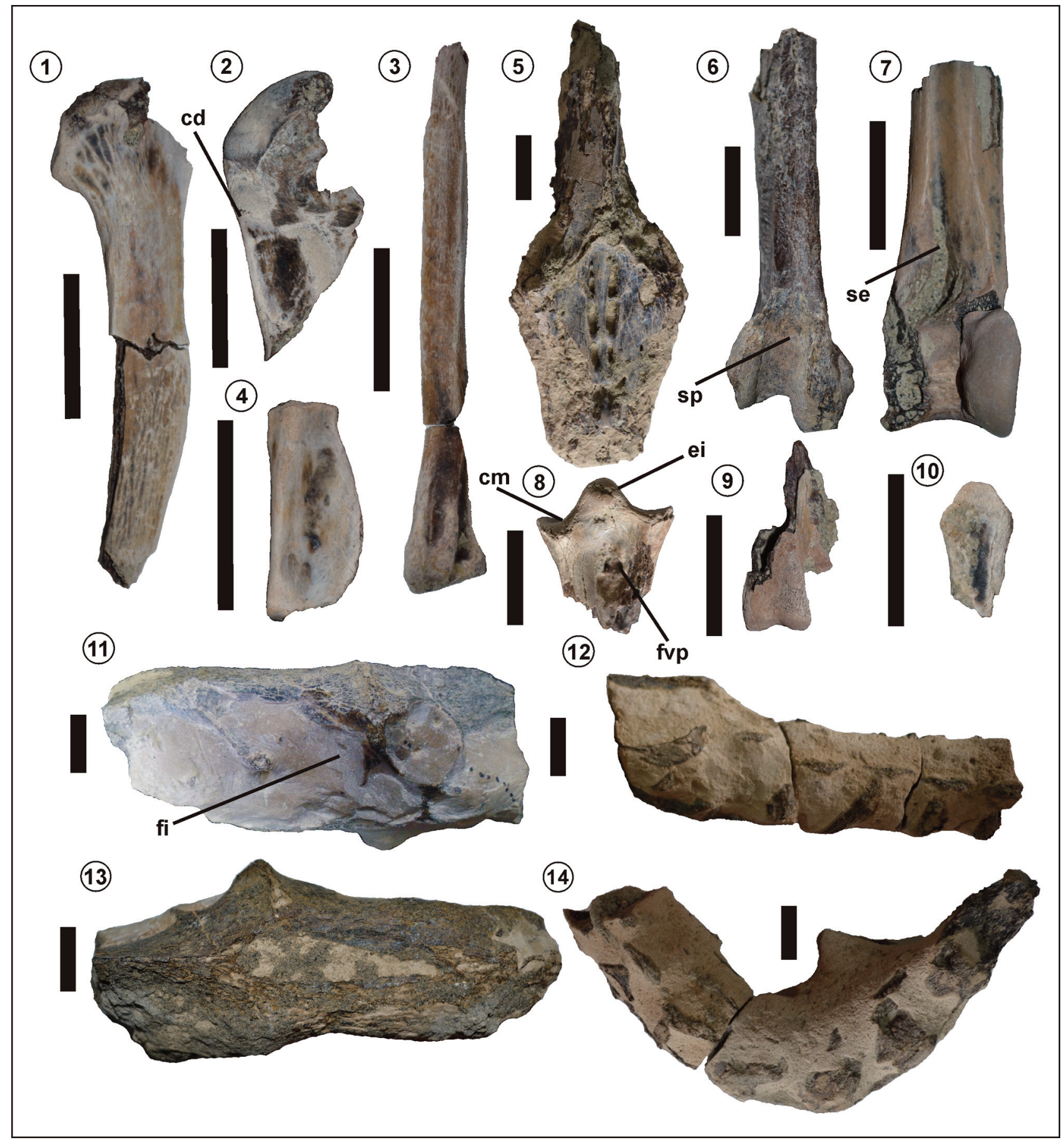

Figure 2. Psilopterus lemoinei. MPM-PV 18897, 1-10; 1, fragments of right scapula, in dorsal view; 2 , proximal end of right humerus in cranial view; 3, distal end of left radius in cranial view; 4, left phalanx proximal digitus majoris of the wing in dorsal view; 5 , fragments of synsacrum in dorsal view; 6, distal end of left femur in cranial view; 7, distal end of left tibiotarsus, in cranial view; 8 , proximal end of right tarsometatarsus in dorsal view; 9 , distal end of left tarsometatarsus in dorsal view; 10, proximal end of indeterminate phalanx of the foot, in dorsal view. MPMPV $18898,11-14 ; 11$, fragments of synsacrum, in lateral view; 12, fragments of posterior ends of column in lateral view; 13, fragments of synsacrum in dorsal view; 14, fragments of anterior ends of column in lateral view. Abbreviations: cd, crista deltopectoralis; cm, cotyla medialis; ei, eminentia intercotylaris; fi, foramen ilioischiadicum; fvp, foramina vascularia proximale; se, sulcus extensorius; sp, sulcus patellaris. Scale bars= $2 \mathrm{~cm}$. 
assignation to Psilopterus bachmanni (Moreno and Mercerat, 1891) and Procariama simplex Rovereto, 1914 (see Alvarenga and Höfling, 2003, table 8).

\section{Psilopterus sp.}

Figure 3.1-2

Referred material. MPM-PV 18901, distal fragment of left tibiotarsus; MPM-PV 18902, distal fragment of left tibiotarsus; MPM-PV 18905, distal end of left tarsometatarsus. Geographic occurrence. MPM-PV 18901 and MPM-PV 18905 come from BB (Estancia Aguada Grande), while MPM-PV 18902, from SBB (Estancia Cordón Alto), Province of Santa Cruz. Stratigraphic occurrence. Santa Cruz Formation (Early-Middle Miocene).

Description. The distal end of tarsometatarsus (MPM-PV 18905) resembles that of Psilopterus lemoinei because its trochlea metatarsi III have flanges more proximally convergent than that of $P$. affinis (Ameghino, 1899) (see Degrange and Tambussi, 2011). The distal fragments of tibiotarsi (MPM-PV 18901, MPM-PV 18902) resemble those of $P$. lemoinei and differ from those $P$. bachmanniby having a wide pons supratendineus with a well-developed distal lip and lateral tubercle (Degrange and Tambussi, 2011). In addition, both remains can be distinguished from $P$. bachmanni by their greater size (see Alvarenga and Höfling, 2003, tab. 8). However, both the tibiotarsus and the tarsometatarsus do not present other characters that allow their complete

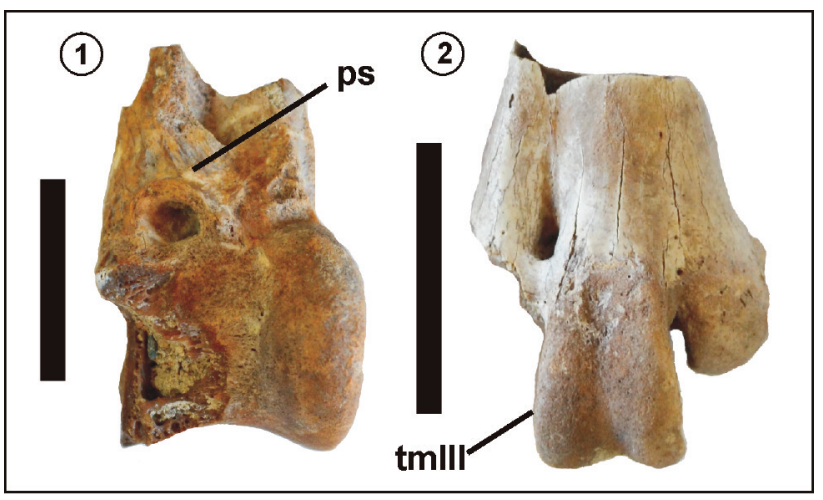

Figure 3. Psilopterus sp. 1, MPM-PV 18902, distal ends of left tibiotarsus in cranial view; 2, MPM-PV 18905, distal ends of left tarsometatarsus in dorsal view. Abbreviations: ps, pons supratendineus; tmIII, trochlea metatarsi III. Scale bars $=2 \mathrm{~cm}$. distinction among the species of Psilopterus and, hence, their tentative assignment to Psilopterus sp.

Order RHEIFORMES (Forbes, 1884)

Family RHEIDAE Bonaparte, 1849

Genus Opisthodactylus Ameghino, 1891

Type species. Opisthodactylus patagonicus Ameghino, 1891. Santa Cruz Formation, Monte Observación, Province of Santa Cruz.

Opisthodactylus patagonicus Ameghino, 1891

Figure 4.1

Referred material. MPM-PV 18903 and MPM-PV 18904, distal ends of left tibiotarsi.

Geographic occurrence. MPM-PV 18903 comes from BB (Estancia Santa Lucía) and MPM-PV 18904, from YH (Estancia El Refugio), Province of Santa Cruz.

Stratigraphic occurrence. Santa Cruz Formation (Early-Middle Miocene).

Description. These specimens are assigned to Opisthodactylus patagonicus. They can be distinguished from other extant and extinct Rheidae by the following character combination (Noriega et al., 2017): prominence for attachment of medial ligament continuous with insertion for transverse ligament (not separated by the distal end of the sulcus extensorius); sulcus extensorius markedly excavated, well delimited and ending proximally; cross-section of distal shaft more markedly compressed anteroposteriorly. Several of the characters observed in both specimens are shared between O. patagonicus and O. kirchneri Noriega, Jordan, Vezzosi and Areta, 2017 but differ from those of 0 . horacioperezi Agnolín and Chafrat, 2015 (see Noriega et al., 2017): greater size; trochlea cartilaginis tibialis larger and more proximodistally developed in anterior view at the point where it joins the medial margin of the condylus lateralis; ridge that delimits trochlea cartilaginis tibialis proximally higher or more proximally extended; in medial view, medial ligamentary ridge sharper, ending distally in a more robust medial ligamental prominence; in lateral view, epicondy/us medialis more marked and more proximally placed. The portion of the sulcus $m$. fibularis located medially to the tuberculum retinaculi $m$. fibularis is developed as in 0. patagonicus but deeper than in O. kirchneri. 
Order TINAMiformes Huxley, 1872

Family TINAMIDAE Gray, 1840

TINAMIDAE gen. et sp. indet.

Figure 4.2

Referred material. MPM-PV 18900, proximal end of left carpometacarpus.

Geographic occurrence. BB (Estancia Santa Lucía), Province of Santa Cruz.

Stratigraphic occurrence. Santa Cruz Formation (Early-Middle Miocene).

Description. A deep pit for an aponeurotic insertion -tentatively identified as the attachment for the ligamentum ulnocarpometacarpale ventralis (Bertelli et al., 2014) - located on the ventral surface of the proximal end, caudal to the processus pisiformis, which is observed in MPM-PV 18900, is an automorphic character for Tinamidae (Bertelli, 2002). Nothocercus Gray, 1867 is the only exception because this pit varies from virtually absent to deep (Bertelli et al., 2014). Additionally, this specimen has the processus extensorious well developed, condition shared with all the tinamids and the European Palaeotis Lambrecht, 1928 among the palaeognathous genera (Mayr, 2015). Other diagnostic character present in MPM-PV 18900 is the "caudal rim" of the trochlea carpalis, which is clearly notched like in some tinamous (e.g., Nothocercus, Tinamus Hermann, 1783, Crypturellus Brabourne and Chubb1914, Eudromia Geoffroy Saint-Hilaire, 1832) (Bertelli et al., 2014).

\section{CONCLUDING REMARKS}

The state of knowledge of the Santacrucian avian diversity was recently summarized by Degrange et al. (2012). The fossil record includes at least 17 formally described species grouped in 15 genera and at least 10 families: rheas (Opisthodactylus patagonicus), tinamous (Crypturellus reai Chandler, 2012), terror birds (Phorusrhacos longissimus Ameghino, 1887; Patagornis marshi Moreno and Mercerat, 1891; Psilopterus bachmanni (Moreno and Mercerat, 1891), Psilopterus lemoinei (Moreno and Mercerat, 1891)), seriemas (Miocariama patagonica Noriega and Mayr, 2017), limpkins (Anisolornis excavatus (Ameghino, 1891)), spoonbills (Protibis cnemialis Ameghino, 1891), falcons (Badiostes patagoniscus
Ameghino, 1895, Thegornis musculosus Ameghino, 1895, T. debilis Ameghino, 1895), waterfowls (Brontornis burmeisteri Moreno and Mercerat, 1891; Eoneornis australis Ameghino, 1895, Eutelornis patagonicus Ameghino, 1895, Ankonetta larriestrai Cenizo and Agnolín, 2010) and darters (Anhinga hesterna (Ameghino, 1895)).

Most of these taxa were originally erected at the end of the $19^{\text {th }}$ century (Ameghino, 1887, 1891, 1895; Moreno and Mercerat, 1891) or restudied at the beginning of the $20^{\text {th }}$ century (Dolgopol de Sáez, 1927; Kraglievich, 1931; Sinclair and Farr, 1932) on the basis of material without precise stratigraphic position or even of dubious geographic provenance.

The most prospected levels of the SCF that have provided the largest amount of avian fossil remains are exposed close to or along the Atlantic Ocean coast (see Fernicola et al., 2019: fig. 5), e.g., Monte León, Monte Observación, La Cueva, Yegua Quemada, Jack Harvey, Puesto Estancia La Costa (Corriguen- Kaik) and Monte Tigre (Ameghino, 1891, 1895; Brodkorb, 1964; Tonni, 1980; Degrange et al., 2012;

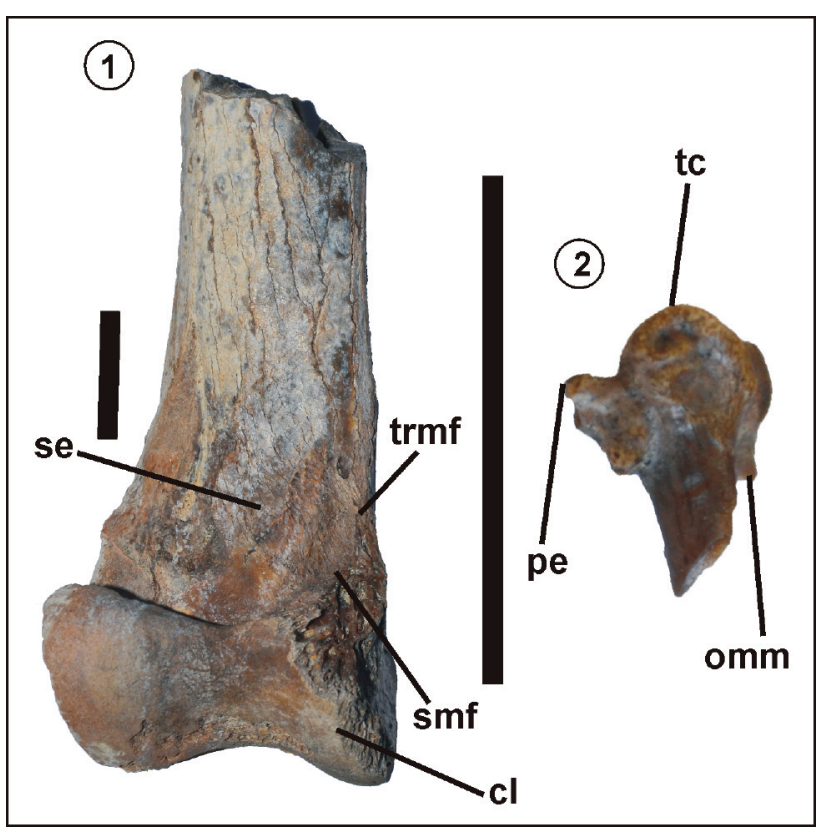

Figure 4. Palaeognathae. 1, Opisthodactylus patagonicus MPM-PV 18903, distal end of left tibiotarsus in cranial view; 2 , Tinamidae indeterminated MPM-PV 18900, proximal end of left carpometacarpus in dorsal view. Abbreviations: cl, condylus lateralis; omm, os metacarpale minus; pe, processus extensorius; se, sulcus extensorius; smf, sulcus $m$. fibularis; tc, trochlea carpale; trmf, tuberculum retinaculi m. fibularis. Scale bars $=2 \mathrm{~cm}$. 
Vizcaíno et al., 2012). Other exposures, such as those in the Río Santa Cruz and Río Chalía (= Sehuén) valleys, have provided limited published information about the fossil record of birds. For example, Carlos Ameghino collected the type specimen of Phorhusracos longissimus Ameghino, 1887 from the Río Santa Cruz outcrops but failed to specify a location. Both the distal end of the tarsometatarsus assigned to the purported limpkin Anisolornis excavatus, as well as the material referred to Psilopterus lemoinei come from Karaiken, north to the rising of Río Santa Cruz, near Lago Argentino; while fragmentary specimens referred to Opisthodactylus patagonicus and Phorhusracos longissimus are reported from localities in Río Chalía (Brodkorb, 1964; Tonni, 1980). Recently, new remains assigned to Phorhusracos longissimus were found near Lago Belgrano (Degrange et al., 2019).

Renewed intensive collecting field trips developed by researchers of MLP, MACN and Duke University, together with paleontological and geologic studies performed since 2003 in the SCF (Vizcaíno et al., 2012; Fernicola et al., 2014), are bringing out the possibility to overcome the historical difficulties concerning the provenances of fossil materials. Thus, the knowledge about some old known Santacrucian bird taxa like the falconid Thegornis musculosus (Noriega et al., 2009, 2011; Noriega and Mayr, 2017) or the phorusrhacid Psilopterus bachmanni (Degrange et al., 2015a) has been substantially improved with new complete or betterpreserved available specimens with accurate provenances.

As a result of the paleontological discoveries within the framework of these projects, we present the first fossil birds collected with precise geological provenance from different localities in the Río Santa Cruz valley. They include fragmentary specimens referred to Opisthodactylus patagonicus (Rheidae) and an indeterminate genus and species of tinamous (Tinamidae), as well as other more complete specimens assigned to Psilopterus lemoinei (Phorusrhacidae). No new remains of Phorhusracos longissimus were recorded.

Santacrucian paleoenvironments were characterized by the presence of alternating areas of herbaceous vegetation with shrubby or wooded areas based on the extrapolation of habitat preferences of living birds for their extinct analogs (Degrange et al., 2012). Habitat preferences of extant rheas, tinamids and seriemas (analog to phorusrhacids) are con- sistent with open areas because of their cursorial capabilities. Additionally, waterfowls, limpkins, spoonbills and darters would indicate the existence of temporarily flooded savannas or permanent water bodies in forested areas (Degrange et al., 2012).

\section{ACKNOWLEDGMENTS}

We want to thank the editors for their invitation to participate in this volume. The comments of two anonymous reviewers helped to improve this contribution. Field work was supported by the following grants: PIP-CONICET 00781 (to J.C. Fernicola), UNLP 11/N867, PICT 2013-0389 (to S.F. Vizcaíno) and 2017-1081 (to M.S. Bargo), National Science Foundation grants 0851272 and 1348259, and National Geographic Society 9167-12 (to R.F. Kay).

\section{REFERENCES}

Agnolín, F., and Chafrat, P. 2015. New fossil bird remains from the Chichinales Formation (Early Miocene) of northern Patagonia, Argentina. Annales de Páleontologie 101: 87-94.

Alvarenga, H., and Höfling, E. 2003. Systematic revision of the Phorusrhacidae (Aves: Ralliformes). Papeis Avulsos de Zoologia, Museu de Zoología da Universidade de São Paulo 43: 55-91.

Ameghino, F. 1887. Enumeración sistemática de las especies de mamíferos fósiles coleccionados por Carlos Ameghino en los terrenos Eocenos de la Patagonia austral y depositados en el Museo de La Plata. Boletín del Museo La Plata 1: 1-26.

Ameghino, F. 1891. Enumeración de las aves fósiles de la República Argentina. Revista Argentina de Historia Natural 1: 441-453.

Ameghino, F. 1895. Sur les oiseaux fossiles de Patagonie. Boletín del Instituto Geográfico Argentino 15: 501-602.

Ameghino, F. 1899. Sinopsis geológico-paleontológica: adiciones y correcciones. Segundo Censo de la República Argentina, p.111-255.

Baumel, J.J., and Witmer, L.M. 1993. Osteologia. In: J.J. Baumel, S.A. King, J.E. Breazile, H.E. Evans, and J.C. Venden Berge (Eds.), Handbook of Avian Anatomy: Nomina Anatomica Avium, second edition. Publications of the Nuttall Ornithological Club 23, Cambridge, p. 45-132.

Bertelli, S. 2002. [Filogenia del orden Tinamiformes (Aves: Palaeognathae). Ph.D. thesis, Universidad Nacional de Tucumán, Tucumán, 160 p. Unpublished.].

Bertelli, S., Chiappe, L.M., and Mayr, G. 2014. Phylogenetic interrelationships of living and extinct Tinamidae, flying paleognathous birds from the New World. Zoological Journal of the Linnean Society 172: 145-184.

Brabourne W.W.K.-H., and Chubb, C.A. 1914. Key to the species of the genus Crypturellus, with descriptions of some new forms. Annals and Magazine of Natural History 14: 319-322.

Brodkorb, P. 1964. Catalogue of fossil birds: Part 2 (Anseriformes through Galliformes). Florida State Museum, Biological Series 8: 195-335.

Cuitiño, J.I., Fernicola, J.C., Kohn, M., Trayler, R., Naipauer, M., Bargo, M.S., Kay, R.F., and Vizcaíno, S.F. 2016. U-Pb geochronology of the Santa Cruz Formation (early Miocene) at the Río Bote and Río Santa Cruz (southernmost Patagonia, Argentina): implications for the correlation of fossil vertebrate localities. Journal of South America Earth Sciences 70: 198-210.

Cuitiño, J.I., Fernicola, J.C., Raigemborn, M.S., and Krapovickas, V. 2019a. Stratigraphy and depositional environments of the Santa 
Cruz Formation (Early-Middle Miocene) along the Río Santa Cruz, Southern Patagonia, Argentina. In: J.C. Fernicola, M.S. Bargo, S.F. Vizcaino, and R.F. Kay (Eds.), Early-Middle Miocene Paleontology in the Río Santa Cruz, Southern Patagonia, Argentina. 130 years since Ameghino, 1887. Publicación Electrónica de la Asociación Paleontológica Argentina 19: 14-33.

Cuitiño, J.I., Vizcaíno, S.F., Bargo, M.S., and Aramendía, I. 2019 b. Sedimentology and fossil vertebrates of the Santa Cruz Formation (early Miocene) in Lago Posadas, a sub-Andean locality of southwestern Patagonia. Andean Geology 46: 383-420.

Degrange, F.J., Eddy, D., Puerta, P., and Clarke, J. 2019. New skull remains of Phorusrhacos longissimus (Aves, Cariamiformes) from the Miocene of Argentina: implications for the morphology of Phorusrhacidae. Journal of Paleontology 93: 1-13.

Degrange, F.J., Noriega, J.I., and Areta, J.I. 2012. Diversity and paleobiology of the santacrucian birds. In: S.F. Vizcaíno, R.F. Kay, and M.S. Bargo (Eds.), Early Miocene Paleobiology in Patagonia: high-latitude paleocommunities of the Santa Cruz Formation. Cambridge University Press, Cambridge, p. 138-155.

Degrange, F.J, Noriega, J.I., and Vizcaíno, S.F. 2015a. Morphology of the forelimb of Psilopterus bachmanni (Aves, Cariamiformes) (Early Miocene of Patagonia). Palaöntologische Zeitschrift 89: 1087-1096.

Degrange, F.J., and Tambussi, C.P. 2011. Re-examination of Psilopterus lemoinei (Moreno and Mercerat, 1891), a late early Miocene little terror bird from Patagonia (Argentina). Journal of Vertebrate Paleontology 31: 1080-1092.

Degrange, F.J., Tambussi, C.P., Taglioretti, M.L., Dondas, A., and Scaglia, F. 2015b. A new Mesembriornithinae (Aves, Phorusrhacidae) provides new insights into the phylogeny and sensory capabilities of terror birds. Journal of Vertebrate Paleontology, 35: 1-18.

Dolgopol de Sáez, M. 1927. Liornis minor, una especie nova de ave fósil. Physis 8: 584-585.

Fernicola, J.C., Bargo, M.S., Vizcaíno, S.F., and Kay, R.F. 2019. Historical background for a revision of the paleontology of the Santa Cruz Formation (Early-Middle Miocene) along the Río Santa Cruz, Patagonia, Argentina. In: J.C. Fernicola, M.S. Bargo, S.F. Vizcaíno, and R.F. Kay (Eds.), Early-Middle Miocene Paleontology in the Río Santa Cruz, Southern Patagonia, Argentina. 130 years since Ameghino, 1887. Publicación Electrónica de la Asociación Paleontológica Argentina 19: 1-13.

Fernicola, J.C., Cuitiño, J.I., Vizcaíno, S.F., Bargo, M.S., and Kay, R.F. 2014. Fossil localities of the Santa Cruz Formation (Early Miocene, Patagonia, Argentina) prospected by Carlos Ameghino in 1887 revisited and the location of the Notohippidian. Journal of South American Earth Sciences 52: 94-107.

Fleagle, J.H., Perkins, M.E., Heizler, M.T., Nash, B., Bown, T.M., Tauber, A.A., Dozo, M.T., and Tejedor, M.F. 2012. Absolute and relative ages of fossil localities in the Santa Cruz and Pinturas Formations. In: S.F. Vizcaíno, R.F. Kay, and M.S. Bargo (Eds.), Early Miocene Paleobiology in Patagonia: high-latitude paleocommunities of the Santa Cruz Formation. Cambridge University Press, Cambridge, p. 41-58.

Geoffroy Saint-Hilaire, I.S. 1832. Eudromia. Magasin de Zoologie 47: classe II, pl. 1.

Gray, G.R. 1867. List of the specimens of birds in the collection of the British Museum. Part V. Gallinae. The order of the Trustees, London, $97 \mathrm{p}$.

Hermann, J. 1783. Tabula Affinitatum Animalium. Imprensis J.G. Treuttel, Argentorati, Strassburg, $164 \mathrm{p}$.

Howard, H. 1929. The avifauna of Emerville shellmound. University of California Publications in Zoology 32: 301-394.

Kraglievich, L. 1931. Contribución al conocimiento de las aves fósiles de la época araucoentrerriana. Physis 10: 304-315.

Lambrecht, K. 1928. Palaeotis weigeltin. g. n. sp., eine fossil Trappe aus der mitteleozanen Braunkohle des Geiseltales. Jahrbuch des Halleschen Verbandes 7: 1-11.

Mayr, G. 2015. The middle Eocene European "ratite" Palaeotis (Aves, Palaeognathae) restudied once more. Paläontologische Zeitschrift 89: 503-514.

Moreno, F.P., and Mercerat, A. 1891. Catálogo de los pájaros fósiles de la República Argentina conservados en el Museo de La Plata. Anales del Museo de La Plata 1: 7-71.

Noriega, J.I., Areta, J.I., Vizcaíno, S.F., and Bargo, M.S. 2011. Phylogeny and taxonomy of the patagonian Miocene falcon Thegornis musculosus Ameghino, 1895 (Aves: Falconidae). Journal of Paleontology 85: 1089-1104.

Noriega, J.I., Jordan, E.A., Vezzosi, R.I., and Areta, J.I. 2017. A new species of Opisthodactylus Ameghino, 1891 (Aves, Rheidae), from the late Miocene of northwestern Argentina, with implications for the paleobiogeography and phylogeny of rheas. Journal of Vertebrate Paleontology 37: e1278005.

Noriega, J.I, and Mayr, G. 2017. The systematic affinities of the putative seriema Noriegavis santacrucensis (Noriega et al., 2009) from the Miocene of Argentina. Contribuciones del Museo Argentino de Ciencias Naturales 7: 133-139.

Noriega, J.I., Vizcaíno, S.F., and Bargo, M.S. 2009. First record and a new species of seriema (Aves: Ralliformes: Cariamidae) from Santacrucian (early-middle Miocene) beds of Patagonia. Journal of Vertebrate Paleontology 29: 620-626.

Perkins, M.E., Fleagle, J.G., Heizler, M.T., Nash, B., Bown, T.M., Tauber, A.A., and Dozo, M.T. 2012. Tephrochronology of the Miocene Santa Cruz and Pinturas Formations, Argentina. In: S.F. Vizcaíno, R.F. Kay, and M.S. Bargo (Eds.), Early Miocene Paleobiology in Patagonia: High-Latitude Paleocommunities of the Santa Cruz Formation. Cambridge University Press, Cambridge, p. 23-40.

Rovereto, C. 1914. Los estratos araucanos y sus fósiles. Anales del Museo Nacional de Historia Natural de Buenos Aires 25: 1-249.

Sinclair, W., and Farr, M. 1932. Aves of the Santa Cruz beds. In: W. Scott (Ed.), Reports of the Princeton University expeditions to Patagonia (1896-1899). Princeton University Press, New Jersey, p. 157-191.

Tonni, E.P. 1980. The present state of knowledge of the Cenozoic birds of Argentina. Contributions in Science 330: 105-114.

Vizcaíno, S.F., Bargo, M.S., Cuitiño, J.I., Pérez, M.E., Muñoz, N.A., Aramendía, I., Tomassini, R.L., and Kay, R.F. 2018. The outstanding Río Chalía (= Sehuén) outcrops of the Santa Cruz Formation (Early Miocene, Burdigalian) and its fossil vertebrate content. Publicación Electrónica de la Asociación Paleontológica Argentina 19: 85R.

Vizcaíno, S.F., Kay, R.F., and Bargo, M.S. 2012. Early Miocene Paleobiology in Patagonia: High-latitude Paleocommunities of the Santa Cruz Formation. Cambridge University Press, Cambridge, 370 p.

Doi: 10.5710/PEAPA.16.09.2019.284

Recibido: 18 de marzo 2019

Aceptado: 16 de septiembre 2019 